KS. WOJCIECH NECEL SCHR

Wydział Prawa Kanonicznego

Uniwersytetu Kardynała Stefana Wyszyńskiego w Warszawie

\title{
WSKAZANIA DLA DUSZPASTERSTWA POLAKÓW POZA GRANICAMI POLSKI
}

Treść: Wprowadzenie. - 1. Walor kanoniczny Wytycznych. - 2. Struktura dokumentu. - 3. Zadania Konferencji Episkopatu Polski wobec rodaków na obczyźnie. - 4. Koordynator krajowy. - 5. Wierni świeccy w polskojęzycznym duszpasterstwie emigracyjnym. - 6. Integracja jako wyzwanie. - 7. Duszpasterstwo polskojęzyczne. Zakończenie.

\section{Wprowadzenie}

Dokument o tytule: Wytyczne Konferencji Episkopatu Polski dotyczace duszpasterstwa emigracji polskiej ${ }^{1}$ zawiera długo wyczekiwane przez środowiska emigracyjne wskazania kanoniczno - pastoralne dla polskojęzycznego duszpasterstwa etnicznego. Zatwierdzone zostały podczas 369. Zebrania Plenarnego Konferencji, które odbyło się w Warszawie w dniach 9-10.06.2015 r. Już na początku analizy Wytycznych trzeba zauważyć, że nie mają one żadnego pierwowzoru, a same w swojej integralności otwarte są na szybko dokonujące się zmiany w duszpasterstwie polonijnym.

\section{Walor kanoniczny Wytycznych}

Po wejściu Polski do Unii Europejskiej potrzeba wypracowania dokumentu dynamizującego duszpasterstwo polonijne była dostrzegana

\footnotetext{
${ }^{1}$ Konferencja Episkopatu Polski, Wytyczne Konferencji Episkopatu Polski dotyczące duszpasterstwa emigracji polskiej (dalej Wytyczne), Tarnów 2015.
} 
coraz bardziej tak przez środowiska polskiej emigracji w Europie Zachodniej, jak i w Ameryce Północnej i Południowej oraz Australii i Nowej Zelandii² .

Duszpasterze bezpośrednio posługujący Polakom na obczyźnie, wspólnie z Polską Radą Duszpasterstwa w Europie Zachodniej pod kierownictwem Delegata Komisji Episkopatu Polski ds. Duszpasterstwa Emigracyjnego, podjęli starania o wypracowanie kanoniczno-duszpasterskich zasad duszpasterstwa polskojęzycznego. Ze względu na niemożność objęcia jednym dokumentem wszystkich sytuacji duszpasterskich inicjatorzy i pracujące komisje uznały, że dokument winien dotyczyć przede wszystkim europejskich środowisk polonijnych oraz ich duszpasterzy. Skierowany jest on zarówno do księży diecezjalnych jak i zakonnych, do sióstr i braci zakonnych, do wiernych świeckich oraz do tych wszystkich którzy w jakikolwiek sposób włączają się w duszpasterstwo polskojęzyczne poza zachodnią i południowa granicą Polski.

Punktem wyjścia prowadzonych prac był charakter udziału Episkopatu Polski w duszpasterstwie polonijnym, a następnie kolejno rola koordynatora krajowego, sytuacja kanoniczna duszpasterza polonijnego a przede wszystkim troska o dobro duchowe Polaków na obczyźnie tak w pierwszym jak i w następnych pokoleniach emigrantów.

Kolejne dokumenty Stolicy Apostolskiej systematyzujące duszpasterstwo migrantów (konstytucja Piusa XII Exsul Familia z 1952 roku $^{3}$, instrukcja Kongregacji Biskupów De pastorali migratorum cura z 1969 r. ${ }^{4}$, instrukcja Papieskiej Rady ds. Duszpasterstwa Migrantów i Podróżujących Erga migrantes caritas Christi z 2004 r. ${ }^{5}$ wraz z nauczaniem Soboru Watykańskiego II oraz dyspozycjami Kodeksu Prawa Kanonicznego z 1983 r. i Kodeksu Kanonów Kościołów

\footnotetext{
${ }^{2}$ Por. W. Necel, Wokół prac nad wytycznymi dla duszpasterstwa emigracji polskiej, Collectanea Theologica 84(2014), nr 2, s. 145-152.

${ }^{3}$ Pius XII, Konstytucja apostolska Exsul Familia, Studia Polonijne 4(1981), s.15-58.

${ }^{4}$ Kongregacja Biskupów, Instrukcja De pastorali migratorum cura, Studia Polonijne 4(1981), s. 61-86.

${ }^{5}$ Papieska Rada ds. Duszpasterstwa Migrantów i Podróżujących, Instrukcja Erga migrantes caritas Christi (dalej EMCC), Lublin 2008.
} 
Wschodnich z 1990 r.) konsekwentnie wskazują, że za duszpasterstwo przybyszów na terenie diecezji ich osiedlenia czy zamieszkania kanonicznie odpowiada tamtejszy biskup diecezjalny (biskup ad quem) ${ }^{6}$. Jednak te same dokumenty również konsekwentnie wskazują, że biskup diecezjalny miejsca pochodzenia przybyszów (biskup a quo) ponosi duszpasterską odpowiedzialność za dobro duchowe emigrujących $\mathrm{z}$ jego diecezji ${ }^{7}$. Zdaniem autorów prezentowanego dokumentu oba Kościoły a quo i ad quem "mogą skutecznie wypełniać swoje zadania jedynie w braterskiej łączności i w ścisłej współpracy ze sobą, w klimacie chrześcijańskiej jedności w różnorodności”8.

Omawiane Wytyczne nie tylko wpisują się w tak określoną współodpowiedzialność zainteresowanych Konferencji Episkopatów i biskupów diecezjalnych, ale w oparciu o wskazane dokumenty Kościoła Powszechnego przybliżają obowiązujące $\mathrm{w}$ duszpasterstwie etnicznym kanoniczne regulacje, osadzając je w realiach duszpasterstwa polskojęzycznego.

Wytyczne same z siebie nie roszczą sobie posiadania kanonicznej wartości dekretu ${ }^{9}$, nakazu ${ }^{10}$ lub instrukcji ${ }^{11}$. Zamieszczone normy o tyle obowiązują, o ile znajdują się w innych normatywnych obowiązujących dokumentach Kościoła. Gdyby miały obowiązujący charakter same przez się, to Konferencja Episkopatu Polski, która ,jest zebraniem biskupów jakiegoś kraju (...) wypełniającym wspólnie pewne zadania pasterskie dla wiernych jej terytorium" ${ }^{12}$, przekroczyłaby zakreślone kanonicznie granice kompetencji i naruszyłaby

\footnotetext{
${ }^{6}$ Wytyczne, nr 9: „Kościół przyjmujący emigrantów (ad quem) jest głównym depozytariuszem odpowiedzialności duszpasterskiej za emigrantów (EMCC 34-51)”.

${ }^{7}$ Por. EMCC art.19-20; W. NeCEL, Biskup „a quo” wobec emigrujących diecezjan, Poznań 2015.

${ }^{8}$ Wytyczne, nr 10.

${ }^{9}$ Kodeks Prawa Kanonicznego (dalej KPK), kan. 48.

${ }^{10}$ Tamże, kan. 49.

11 Tamże, kan. 34 par. 1.

12 Tamże, kan. 447.
} 
dyspozycje kan. 381 par. $1 \mathrm{KPK}^{13}$. Dlatego też w nr. 2 omawianego dokumentu znajduje się zapis: „Kościół w Polsce, z racji swojej duszpasterskiej misji, jest zainteresowany losami emigrantów poza granicami Ojczyzny. Znając gwarancje kanoniczne i duszpasterskie zawarte w dokumentach Stolicy Apostolskiej oraz szanując kompetencje Kościołów lokalnych i odpowiedzialność kanoniczną i duszpasterską tamtejszych biskupów za opiekę nad migrantami, biskupi polscy wydają niniejsze Wytyczne, które należy traktować jako praktyczne zasady związane z duszpasterstwem polskojęzycznym na emigracji, konkretyzujące ogólne normy duszpasterstwa emigrantów"14.

\section{Struktura dokumentu}

Trzeba zauważyć, że Wytyczne są dokumentem bardzo skromnym nie tylko co do formatu, ale i objętości. Być może biskupom chodziło o to, by swoją skromnością zaintrygowały one zainteresowane środowiska do analitycznej lektury oraz do podjęcia realizacji zawartych wskazań. Jednak przyjęta forma powoduje, że znajdujemy w nim liczne niedoprecyzowania, uogólnienia lub pominięcia.

Oprócz Wstępu i Zakończenia Wytyczne podzielone są na trzy rozdziały zatytułowane kolejno: Organizacja duszpasterstwa, Osoby zaangażowane w duszpasterstwo polskojęzyczne oraz Podstawowe funkcje duszpasterskie.

W pierwszym rozdziale oprócz zasad ogólnych (nr 5-11) usystematyzowane są struktury duszpasterstwa polskojęzycznego (nr 12-19). W kolejnych artykułach (nr 20-29) wraz z licznymi podpunktami) omówiona jest rola koordynatora krajowego. W drugim rozdziale wskazana jest rola kapłanów diecezjalnych (nr 30-36), osób konsekrowanych przez profesję rad ewangelicznych i członków stowarzyszeń życia apostolskiego (nr 37-42) oraz osób świeckich (nr 43-51) w duszpasterstwie polskojęzycznym poza granicami Ojczyzny. W ostatnim

\footnotetext{
${ }^{13}$ Tamże, kan. 381 par. 1: Biskupowi diecezjalnemu w powierzonej mu diecezji przysługuje wszelka władza zwyczajna, własna i bezpośrednia, jaka jest wymagana do jego pasterskiego urzędu (...)".

${ }^{14}$ Wytyczne, nr 2.
} 
rozdziale podjęta jest specyfikacja posługi duszpasterskiej na rzecz polskich emigrantów w trzech podstawowych zakresach: posługi słowa (nr 52-57), posługi sakramentów (nr 58-63) oraz posługi miłości pasterskiej (nr 64-75).

\section{Zadania Konferencji Episkopatu Polski wobec rodaków na obczyźnie}

Wytyczne z jednej strony konsekwentnie podkreślają kanoniczną zasadę, że wszystkie placówki duszpasterstwa polonijnego „są integralną częścią (tamtejszego) lokalnego Kościoła. Dlatego do kompetencji biskupa diecezjalnego (ad quem) należy" zgodnie z prawem erygowanie i modyfikowanie struktur duszpasterskich dla polskojęzycznych środowisk emigracyjnych ${ }^{15}$, zapewnienie odpowiedniej posługi duszpasterskiej i właściwego miejsce kultu ${ }^{16}$. Warto zauważyć, że artykuł 12. Wytycznych w swojej ofercie kanoniczno-duszpasterskiej jest uboższy w stosunku do treści nr. 91 EMCC.

Patronacka koordynacja kompleksowej posługi dla dobra duchowego polskich emigrantów w poszczególnych państwach Europy Zachodniej należy do Konferencji Episkopatu Polski ${ }^{17}$. Funkcję tę Konferencja sprawuje poprzez wybieranego na 5-letnią kadencję Delegata Konferencji Episkopatu Polski ${ }^{18}$ ds. Duszpasterstwa Emigracji Polskiej ${ }^{19}$, który równocześnie sprawuje funkcję przewodniczącego Komisji KEP ds. Polonii i Polaków za Granicą ${ }^{20}$. Delegat w swojej

\footnotetext{
${ }^{15}$ KPK kan. 516 par. 2 i kan. 568; EMCC 91.

${ }^{16}$ Wytyczne, nr 12.

${ }^{17}$ Wskazania, nr 8.

${ }^{18}$ Konferencja Episkopatu Polski (dalej KEP).

${ }^{19}$ Tamże, nr 15. Do zadań Delegata należy współpraca z biskupami lokalnymi, na terenie których znajdują się skupiska polskich emigrantów. Winien utrzymywać stałe kontakty z konferencjami biskupów i ich delegatami, zajmującymi się duszpasterstwem emigrantów. Bierze on czynny udział w procesie powstawania nowych placówek duszpasterstwa polskojęzycznego, jest łącznikiem pomiędzy strukturami duszpasterstwa polonijnego a biskupami w Polsce, służy pomocą środowisku emigracyjnemu w sprawach duszpasterskich.

${ }^{20}$ Tamże, nr 14.
} 
trosce o migrantów posługuje się powołanym przy Sekretariacie KEP Biurem Delegata $^{21}$.

\section{Koordynator krajowy}

Omawiany dokument na jednym $\mathrm{z}$ czołowych miejsc w trosce o dobro duchowe polskich emigrantów stawia koordynatora krajowego, który w tradycji duszpasterstwa polonijnego zwany jest „rektorem”. Warto zwrócić uwagę, że Wytyczne nie używają terminu „koordynator krajowy”, ale „koordynator duszpasterstwa”. Wydaje się, że zmiana ta nie ma tylko charakteru czysto stylistycznego. W swoistej nadinterpretacji może niesie ze sobą zmianę zakresu jego posługi, co w jakiś sposób może być sprzeczne z tradycją tej funkcji w historii duszpasterstwa emigracyjnego ${ }^{22}$ oraz z dyspozycjami Erga migrantes $^{23}$. W EMCC znajdujemy zapis: „Wśród operatorów duszpasterskich w służbie migrantów znaczące miejsce zajmuje krajowy koordynator, który zostaje ustanowiony bardziej jako pomoc dla kapelanów/misjonarzy jakiegoś języka czy kraju, niż dla samych migrantów, jak również jest wyrazem troski Kościoła ad quem o kapelanów/misjonarzy migrantów. Choć nie jest uważany za ich przedstawiciela służy on kapelanom/misjonarzom (...) w krajach o dużej ilości migrantów pochodzących z konkretnego kraju"24.

Powstanie w przeszłości funkcji najpierw dyrektora duszpasterzy (w konstytucji Exsul Familia), później delegata misjonarzy (w instrukcji De Pastoralis Migrantorum Cura) i wreszcie koordynatora krajowego (w instrukcji Erga migrantes caritas Christi) wiąże się raczej z troską o samych duszpasterzy. Misjonarz/kapelan migrantów pracuje bardzo często $\mathrm{z}$ dala od swojego ordynariusza w trudnych warunkach, które mogą zagrażać jego tożsamości kapłańskiej i powodować moralne zagubienie oraz osamotnienie. Dlatego też

\footnotetext{
${ }^{21}$ Tamże, nr 16.

${ }^{22}$ Por. M. Francesconi, Giovanni Battista Scalabrini apostolo degli emigranti, w: Per una pastorale dei migranti, Roma 1980, s. 21-45.

${ }^{23}$ EMCC 73-74.

${ }^{24}$ Tamże, nr 73.
} 
koordynator z racji swojej funkcji i zgodnie z tradycją duszpasterstwa migracyjnego stoi raczej przy osobie kapelana/misjonarza niż przy dziele ewangelizacji środowisk emigracyjnych. Tak jak nie posiada żadnej władzy jurysdykcyjnej wobec kapelanów/misjonarzy, tak również „nie posiada bezpośredniej kompetencji wobec migrantów”25. Stąd niezrozumiały jest zapis nr 19 Wytycznych, który zobowiązuje koordynatora do „podejmowania działań duszpasterskich i organizacyjnych” dla dobra migrantów. Natomiast bardzo wskazane i wynikające z tradycji jest to, że do koordynatora należy troska o życie duchowe duszpasterzy polskich emigrantów oraz udzielanie konkretnej pomocy nowoprzybyłym duszpasterzom, a także starszym i schorowanym, przeżywającym trudności duchowe bądź materialne.

W omawianym dokumencie koordynator krajowy dodatkowo otrzymuje zadanie reprezentowania Konferencji Episkopatu Polski w polskojęzycznym duszpasterstwie. Szkoda, że Wytyczne nie precyzują w tym względzie relacji pomiędzy nim a Delegatem KEP ds. Duszpasterstwa Emigracji Polskiej.

W wielu krajach, w których jest prowadzone i rozwijane duszpasterstwo polskojęzyczne, miejscowe Konferencje Episkopatów nie mianowały koordynatora krajowego. Według zapisu nr. 29 Wytycznych KEP może w tych przypadkach jednostronnie mianować swojego delegata. Dobrze byłoby, żeby dla jasności sytuacji nie posługiwał się on tytułem „koordynatora” lub „rektora”, a po prostu był „przedstawicielem KEP” „dla” i „wśród” duszpasterzy polonijnych ${ }^{26}$.

\section{Wierni świeccy w polskojęzycznym duszpasterstwie emigracyjnym}

W ostatniej części II rozdziału Wytycznych znajduje się kilka artykułów poświęconych roli laikatu w duszpasterstwie etnicznym. Pomijając treść poszczególnych zapisów, na uwagę zasługuje przyjęty przez autorów inny porządek niż w instrukcji Papieskiej Rady Erga migrantes. Jest to o tyle ważne, że w duszpasterstwie polonijnym to

\footnotetext{
25 Tamże, nr 74; art.11 par. 4.

${ }^{26}$ Wytyczne, 29.
} 
sami emigranci jako wierni świeccy byli protagonistami adekwatnej opieki duszpasterskiej ${ }^{27}$ i oni sami również dzisiaj wskazują na zapotrzebowanie duszpasterskie, a przede wszystkim to oni wypełniają polskojęzyczne ośrodki duszpasterskie. Oprócz tego przynależne im miejsce wskazane w Erga migrantes wychodzi naprzeciw stanowi liczbowemu powołań kapłańskich, a więc i powołań do duszpasterstwa emigracji polskiej o czym należy też rozmawiać. Wytyczne pominęły konieczność poszerzania i pogłębiania współpracy z laikatem i potrzebę stopniowego przekazywania mu odpowiedzialności i zadań przewidzianych tak w prawie powszechnym Kościoła, jak i w prawodawstwie poszczególnych diecezji, w których znajdują się polskojęzyczne ośrodki duszpasterskie. Współpraca ta wymaga wszechstronnego przygotowania laikatu, co też zostało pominięte $\mathrm{w}$ omawianym dokumencie.

Wydaje się, że szczątkowo zapisane prawo i obowiązek świeckich do „aktywnego udziału w życiu Kościoła i w jego misji ewangelizacyjnej" ${ }^{28}$ oraz szczątkowe potraktowanie roli małżeństwa i rodziny w duszpasterstwie emigracyjnym ${ }^{29}$ są ciągle żywą pochodną traktowania duszpasterstwa polonijnego jako duszpasterstwa „dla” emigrantów. Tymczasem obowiązująca od 2004 roku instrukcja Papieskiej Rady Erga migrantes duszpasterst wo emigracyjne określa jako duszpasterstwo dialogu, komunii oraz misji i jako takie winno być prowadzone nie tylko „dla” emigrantów, ale równolegle „wśród nich i z nimi" ${ }^{30}$ i to nie tylko w pierwszym, ale w kolejnych pokoleniach „aż do pełnego uczestnictwa migrantów w życiu diecezjalnym”31.

\section{Integracja jako wyzwanie}

Wytyczne w roku obchodzenia 1050 rocznicy chrztu Polski mogą ożywić wielopokoleniowe środowiska polskich emigrantów i ich

\footnotetext{
${ }^{27}$ Por. EMCC 91.

${ }^{28}$ Wytyczne, nr 43.

${ }^{29}$ Por. Tamże, nr 48; 69-70.

${ }^{30}$ EMCC 100.

${ }^{31}$ Tamże, nr 77.
} 
duszpasterzy. Bardzo ważnym przesłaniem omawianego dokumentu jest wskazanie, za instrukcją Erga migrantes, na wieloaspektową integrację polskich emigrantów w diecezjach i wspólnotach parafialnych miejsca zatrzymania i osiedlenia jako na podstawową zasadę duszpasterstwa polonijnego ${ }^{32}$. Jest to wyraźnie odcięcie się od prób tworzenia gett przez polskojęzyczne środowiska oraz od traktowania polskojęzycznej posługi duszpasterskiej w warunkach emigracyjnych jako kliszy duszpasterstwa w Polsce ${ }^{33}$. Tak przyjęta zasada duszpasterska jest fundamentem wielopokoleniowego procesu przechodzenia środowisk polskich emigrantów w środowiska mniejszości etnicznych polskiego pochodzenia. W nr. 4 Wytycznych biskupi polscy z troską zapisali, że „,integracja nie oznacza asymilacji, czyli zatracenia własnej tożsamości, lecz dynamiczny proces, w którym emigranci i miejscowi łączą się harmonijnie w jedną społeczność poprzez wzajemne poznanie, dostosowanie i ubogacenie własnymi wartościami etnicznymi. Ten naturalny proces przebiega etapami w formie zewnętrznej akomodacji, następnie adaptacji i stopniowego włączania się emigranta w nurt życia całej społeczności, zawsze jednak spontanicznie i dobrowolnie, bez żadnego przymusu czy przeszkód w zachowaniu przez nich własnej tożsamości kulturowej. W rezultacie pełny proces integracyjny może trwać nawet kilka pokoleń" ${ }^{34}$.

\section{Duszpasterstwo polskojęzyczne}

Zadaniem polskojęzycznego duszpasterstwa na emigracji jest umożliwienie Polakom na obczyźnie i wiernym posługującym się językiem polskim korzystania z duszpasterstwa prowadzonego podobnie jak we wspólnocie pochodzenia lub kraju rodzinnym. Rodzi się pytanie o rolę języka polskiego w definiowaniu duszpasterstwa

\footnotetext{
${ }^{32}$ Por. EMCC 77.

${ }^{33}$ Wskazania, nr 4: „(...) za sprzeczne z postawą integracyjną należy uznać zarówno duszpasterstwo uniformistyczne, lekceważące wartości etniczno-kulturowe emigrantów, jak i duszpasterstwo nacechowane etnocentryzmem”. Por. PAwEŁ VI, Motu proprio Pstoralis migratorum cura, Studia Polonijne 4(1981), s. 59-60.

${ }^{34}$ Wskazania, nr 4.
} 
polskojęzycznego na emigracji i określenia tych wiernych, do których jest ono skierowane i którzy gromadzą się w ośrodkach duszpasterskich Polskiej Misji Katolickiej.

Duszpasterz polonijny w swojej posłudze staje przed dylematem praktycznym: czy Ewangelia służy językowi, czy język jest na usługach Ewangelii? W poszukiwaniu pastoralnej odpowiedzi winien on zdawać sobie sprawę, że dla migrantów już nawet w II pokoleniu język polski jest językiem drugim lub nawet trzecim. Językiem podstawowym, służącym do codziennej zwyczajnej komunikacji czyli „językiem serca”, często nie jest już język polski, ale miejscowy, w którym wzrastali. Język miejscowy służy też do pogłębiana zagadnień wiary, do rozwiązywania problemów i dylematów moralnych i światopoglądowych, do budowania koniecznych relacji ze środowiskiem. Trzeba też pamiętać, że w niedzielnej celebracji Mszy św. w ośrodku Polskiej Misji Katolickiej mogą uczestniczyć małżonkowie, z których jedno nie jest polskiego pochodzenia i nie zna języka polskiego, albo ich dzieci i wnuki. Taka sama sytuacja może zaistnieć w korzystaniu z sakramentu pokuty lub uczestnictwa w katechezie przedchrzcielnej dla rodziców lub chrzestnych oraz w czasie konferencji przedmałżeńskich ${ }^{35}$. Jak rozumieć termin „duszpasterstwo polskojęzyczne”? Czy nry 52-75 Wytycznych upoważniają do stwierdzenia, że w polskojęzycznych ośrodkach posługujemy się tylko i wyłącznie językiem polskim?

Pytanie o język jest równocześnie pytaniem o duszpasterza. Szkoda, że w Wytycznych tak mało miejsca poświecono duszpasterzowi i jego obowiązkowej dwukulturowości. Stolica Apostolska w trosce o dobro duchowe migrantów przestrzega, że „bycie kapelanem/misjonarzem eiusdem sermonis nie oznacza jednak pozostawanie więźniem w granicach jedynego, wyłącznego, narodowego sposobu przeżywania i wyrażania wiary"36. A czy można przecenić rolę duszpasterza $\mathrm{w}$ procesie integracji migranta?

\footnotetext{
${ }^{35}$ Por. Tamże, nr 55.

${ }^{36}$ EMCC 77.
} 


\section{Zakończenie}

Wytyczne mają ,charakter pastoralny i są wyrazem troski Konferencji Episkopatu Polski o emigrantów, którzy opuścili swój kraj rodzinny, by zachowali więź z Bogiem i Kościołem, z bogatym dziedzictwem praktyk, tradycji i zwyczajów religijnych wyniesionych z ojczyzny" ${ }^{37}$. Z drugiej strony mają umacniać duszpasterzy migrantów w ich posłudze polskim migrantom w pierwszej i następnych generacjach $\mathrm{w}$ wielopokoleniowym procesie integracji ${ }^{38}$. Jednak duszpasterz środowisk polonijnych, będący jednym $\mathrm{z}$ ważniejszych adresatów Wytycznych, nie znajduje w nich odniesienia do „wymienialności” polskojęzycznych środowisk emigracyjnych. Przecież w sprawowanej posłudze winien on uwzględnić dwie istotne cechy każdego skupiska polonijnego.

Pierwszą z nich jest dynamiczna zmienność środowiska migrantów i ciągły napływ nowych. Niebezpieczeństwem dla duszpasterstwa polonijnego jest każdorazowe zamykanie się środowiska na nowoprzybyłych lub przebywających czasowo na kontraktach, na studiach czy z innych racji. W Wytycznych nie wspomina się również o konieczności i sposobach docierania do Polaków nowoprzybyłych na teren misji, tak jakby byli oni ze względu na swoją sytuację życiową poza strefą zainteresowania duszpasterza.

Drugą jest wielopokoleniowość diaspory Polaków na obczyźnie, a zatem bardzo zróżnicowany stopień ich integracji. Salus animarum jako podstawowa zasada działalności apostolskiej Kościoła w warunkach polonijnych przybiera postać procesu integracji eklezjalnej polskich rzesz emigracyjnych, czyli stopniowego i wielopokoleniowego włączania się w struktury Kościoła miejsca zamieszkania. Duszpasterz polonijny musi brać pod uwagę, że w czasie niedzielnej Mszy św. lub innych celebracji sakramentalnych i pozasakramentalnych wspólnota, której przewodniczy, jest strukturalnie zróżnicowana. Obok nowoprzybyłego z Polski modli się wierny będący potomkiem migranta w trzecim czy dalszym pokoleniu. Jeżeli nawet socjolog

\footnotetext{
${ }^{37}$ Wytyczne, nr 76.

${ }^{38}$ Tamże, nr 4.
} 
opisze dokładnie strukturę wspólnoty wiernych danego ośrodka polskojęzycznego, to dla duszpasterza opis ten ma drugorzędne znaczenie. Swoją posługą buduje on paschalną wspólnotę wiary, nadziei i miłości z wszystkimi którzy gromadzą się w polskojęzycznym ośrodku duszpasterskim. Nikogo nie może wykluczyć.

Należy również zwrócić uwagę na pewne wymieszanie posługi caritas $^{39} \mathrm{z}$ ważnym elementem duszpasterstwa polskojęzycznego, jakim jest tzw. pobożność ludowa. Trzeba pamiętać, że nie ma „ogólnopolskiej pobożności ludowej”. Istotnym faktorem charakteryzującym posługę polonijną jest zróżnicowanie wiernych pod względem pochodzenia $\mathrm{z}$ różnych regionów Polski. Żadna z pobożności regionalnych nie może dominować w polskojęzycznym ośrodku duszpasterskim, a tym bardziej nie mogą dominować zwyczaje religijne wywiezione przez duszpasterza ze swojej małej ojczyzny. Z innymi lub inaczej przeżywanymi zwyczajami religijno-ludowymi wyjechał emigrant z Polski w okresie Solidarności, z innymi na przełomie wieków, a z jeszcze innymi ten, który opuszczał Polskę po włączeniu Rzeczpospolitej do struktur Unii Europejskiej.

Jednak pomimo wskazanych braków należy podkreślić, że tak ważna dla Kościoła w Polsce działalność duszpasterska znalazła rodzimą próbę swojego kanoniczno-duszpasterskiego opisania. Wobec szybko zachodzących zmian Wytyczne nie tyle opisują instytucjonalność polskojęzycznej posługi duszpasterskiej poza granicami Polski, ale otwierają nowe możliwości i wskazują nowe wyzwania. W zakończeniu dokumentu zamieszczony jest zapis, że „wytyczne zostały zatwierdzone na okres 3 lat”. Zdobyte w tym okresie doświadczenia, kolejne cenne uwagi duszpasterzy polonijnych oraz refleksja kanoniczno-pastoralna pozwolą na wypracowanie jeszcze bardziej potrzebnego środowisku emigracyjnemu dokumentu.

\footnotetext{
${ }^{39}$ Zob. W. NecEL, Motu proprio Benedykta XVI "Intima Ecclesiae natura" wobec troski Kościoła o imigrantów, Prawo Kanoniczne 56(2013) nr 4, s. 65-76.
} 


\section{Guidelines for the pastoral care of Poles abroad Polish}

Wytyczne Konferencji Episkopatu Polski dotyczace Duszpasterstwa Emigracji Polskiej is a document approved at the 369th Plenary Sitting of the Conference that took place in Warsaw on 9-10 June 2015. The necessity to develop Wytyczne had been recognized by Polish migration communities for a long time. Priests directly working for Poles in exile, together with Polish Council of Pastoral Care in Western Europe under the authority of the delegate of Polish Episcopal for Pastoral care of emigration, made efforts to develop general instructions for Polish-language ministry. Initiators and working committees stated that the document should take into consideration all Polish communities and their priests. Wytyczne is a document addressed to secular and monastic clergy, monks and nuns, who take care of Poles in exile's spiritual well-being and to those who participate in taking care of Polish emigrants.

SŁOWA KLUCZOWE: biskup a emigrant, Konferencja Episkopatu Polski, polska emigracja, duszpasterstwo, integracja, język a duszpasterstwo, struktura duszpasterstwa polskojęzycznego, duszpasterz migrantów

Keywords: bishop and emigrant, Polish Episcopal Conference, Polish migration, priesthood, Pastoral Ministry, pastoral care, integration, language and priesthood, the structure of Polish-language Ministry, a priest of migrants

\section{Nota o Autorze:}

KS. DR HAB. WOJCIECH NeCEl SChr, PROF. UKSW - profesor nadzwyczajny na Wydziale Prawa Kanonicznego UKSW w Warszawie, kierownik zakładu Historii Źródeł i Literatury Prawa Kanonicznego w katedrze Historii Prawa Kanonicznego. 